\title{
INDUCTION OF DEPRESSION MODEL IN MICE: IMPLICATION OF DIFFERENT RESERPINE DOSES
}

\author{
Abou-Nour, Afaf, A. ${ }^{(1)}$; Ali, Elham, H. A. ${ }^{(1)}$; Farid, O. A. ${ }^{(2)}$ \\ and Abou-khzam, Barga, A. F. \\ 1) Faculty of Women for Arts, Science and Education, Ain Shams University. \\ 2) National Organization for Drug Control and Research
}

\begin{abstract}
Depression is a mood disorder whose main clinic characteristics include lasting low motion, decrease in motivate ability and slowness in function of thinking and recognizing. It is showed in national survey that the suicide rate of people suffering from depression is 20 times higher than that of normal people. The present study aimed to select the most suitable dose of reserpine for induction of depression in mice with minimal side effects and minimal mortality rate. Depression was induced in mice by a single i.p. reserpine injection at different dose $(0.1,0.5$ and $1 \mathrm{mg} / \mathrm{kg})$ at the day 1 , then forced swimming test was performed 1 hour later at the first day. The duration of the experiment was 2 days. The mortality rate was recorded, The brain was excised and prepared for determination of the content of the Adenosine monophosphate (AMP), adenosine Diphosphate (ADP) and Adenosine triphosphate (ATP), Monoamine neurotransmitters (5-HT, DA and NE), Malondialdehyde (MDA), Nitric oxide (NO), Glutathione reduced (GSH), oxidized (GSSG) and 8- hydroxyl-2-deoxyguanosine (8-OHDG). The forced swimming test and number of jumping showed no significant difference between different doses while the mortality rate was markedly variable. The results concluded that the most suitable reserpine dose for inducing depression with minimal mortality was $0.1 \mathrm{mg} / \mathrm{kg}$ of body weight.
\end{abstract}

Key words: Depression - reserpine. 
J. Environ. Sci.

Institute of Environmental Studies and Research - Ain Shams University

\section{INTRODUCTION}

Depression is one of the most common neuropsychiatric disorders that affect approximately 20\% of the world population (Thakare and Patel, 2015). It can be caused by one or more changes in the brain, which may or may not be directly related. These changes may include monoamine neurotransmitters depletion, cellular atrophy, neuronal death or decreased neurogenesis (Hurley et al., 2014). Also depression is a neuro-psychiatric illness that involves the whole body, mood and thoughts and affects the way a person eats, sleeps, feels about himself or herself and thinks about things. It is a mood disorder that causes a persistent feeling of sadness and loss of interest. Also called major depressive disorder or clinical depression, it can lead to a variety of emotional and physical problems (Willner et al., 2013). People who are depressed often have anxiety as well the two problems often occur together, and each can make the other worse. Feeling anxious makes the mind full of busy, repetitive thoughts, which make it hard to concentrate, relax, or sleep. People may have physical symptoms, such as headaches, aching muscles, sweating and dizziness. Anxiety may cause physical exhaustion and general ill health and sometimes accompanied with suicidal thoughts (Gotlib and Joormann, 2010 and Croy et al., 2014).

Depression has been linked to problems or imbalances in the brain with regard to the Neurotransmitters Serotonin, Norepinephrine, and Dopamine. The evidence is somewhat indirect on these points because it is very difficult to actually measure the level of neurotransmitter in a brain. Antidepressant 
medications which used to treat depression are known to act upon these particular neurotransmitters and their receptors (Porcelli et al., 2011).

Reserpine appears naturally in the dried roots of plants such as Rauwolfia Serpentina and Vomitoria. It is an indole alkaloid antipsychotic and antihypertensive drug that has been used for the control of high blood pressure and for the relief of psychotic symptoms (Dong et al., 2009 and Ranganath et al., 2013). The antihypertensive actions of Reserpine are a result of its ability to deplete catecholamines from peripheral sympathetic nerve endings. These substances are normally involved in controlling heart rate, force of cardiac contraction and peripheral resistance (Ranganath and Raj, 2015). After chronic administration of this drug some patients complained of major depression in 1950's (Lieth and Barrett, 1980). On the other hand, Henry et al. (1998) found that reserpine irreversibly blocks the intracellular vesicles monoamine transporters. This blockage overlap with the storage of monoamines into the intracellular vesicles, which effect in the depletion of catecholamines in nerve terminals and transient hypolocomotion and muscular rigidity.

The a ccumulation of neurotransmitters in the nerve terminal leads to a raise in the metabolism of these substances by monoamine oxidase. These can lead to the formation of reactive metabolites and hydrogen peroxide, producing free radicals and cellular damage by increased oxidative stress (albilio et al., 2003 and Bilska et al., 2007).

The experiment was held to select the most suitable dose of reserpine for induction of depression in mice with minimal side effects and minimal mortality rate on mice in Egypt conditions. 


\section{MATERIAL AND METHODS}

Animals: Animals used were sixty adult male albino mice weighing 20-25 g. purchased from National Research Centre (NRC, Cairo, Egypt). Upon arrival the animals were acclimatized for 7 days to a quiet colony room, with controlled ambient temperature $\left(22 \pm 2{ }^{\circ} \mathrm{C}\right)$ and a 12 hour natural light/dark cycle, fed a standard diet and water was provided ad libtum.

Doses and injections: Reserpine was dissolved in glacial acetic acid and then diluted to a final concentration with distilled water, given to the mice at a single dose of $0.1,0.5,1 \mathrm{mg} / \mathrm{kg}$ i.p of body weight according to Freitas et al. (2016) at the first day of the experiment.

Experimental design: The experiment divided into 4 groups 15 for each normal control, reserpine $0.1,0.5$ and $1 \mathrm{mg} / \mathrm{kg}$. The mortality rate was recorded daily. All the groups injected intraperitoneal (i.p) a single dose of reserpine at the day 1 , then forced swimming test was performed 1 hour later. The mice were left to rest at the second day and finally were sacrificed by decapitation at the $3^{\text {rd }}$ day. The brain was excised and prepared for determination of Adenosine monophosphate (AMP) contents, adenosine Diphosphate (ADP) contents and Adenosine triphosphate (ATP) contenst, Monoamine neurotransmitters contents (Serotonin (5-HT), Norepinephrine (NE) and Dopamine (DA)), Malondialdehyde (MDA) contents, nitric oxide (NO) contents, Glutathione reduced (GSH) content , oxidized (GSSG) contents and 8-hydroxyl-2-deoxyguanosine (8-OHDG) contents. 
Forced Swimming Test: Each mice was placed for 6 minutes in a cylindrical water tank (40 cm high, $40 \mathrm{~cm}$ diameter) where, water level was about $25 \mathrm{~cm}$ and water temperature was maintained at $23^{\circ} \mathrm{C}$ to $25^{\circ} \mathrm{C}$. The total duration of immobility time and the Jumbing numbers of each animal in the last 4 minutes was recorded (Porsolt et al., 1977).

Biochemical assays: Brain tissue was homogenized in $75 \%$ aqueous HPLC grade methanol $(10 \% \mathrm{w} / \mathrm{v})$. The homogenate was spun at 4000 r.p.m. for 15 minutes and the supernatant was isolated. The detection of Adenosinnes (AMP, ADP and ATP) by HPLC was done according to the method of Liu et al. (2006). Brain monoamines (5-HT, NE and DA) were detected by HPLC according to method described previously (Pagel et al., 2000). Brain NO content was determined using HPLC according to Papadoyannis et al. (1999). The determination of MDA according to Ruiz-Larrea et al. (1994) and (GSH, GSSG) according to Bulaj et al. (1998) and Ellman (1959) by HPLC. 8hydroxyl-2-deoxyguanosine (8-OHDG) Isolation and hydrolysis of brain 8OHDG was performed as previously described (Lodovici et al., 1997).

Statistical Analysis: Reported values represent means \pm SE. Statistical analysis was evaluated by one -way ANOVA. Once a significant F test was obtained, LSD comparisons were performed to assess the significance of differences among various treatment groups. Statistical package for social science "SPSS" for Windows software, Release 18.0 (SPSS, Chicago, IL) was used at $p$ value $\leq 0.05$. 
J. Environ. Sci.

Institute of Environmental Studies and Research - Ain Shams University

\section{RESULTS}

Mortality rate: The mortality percentage of groups given different doses of reserpine illustrated in Table 1 and Figure 1. It was clearly noticed that the mortality percentage is directly proportional to the increase in reserpine dose; the highest mortality percentage was in reserpine $1 \mathrm{mg}$ followed by reserpine $0.5 \mathrm{mg}$ and eventually reserpine $0.1 \mathrm{mg}$ which recorded the lowest mortality rate compared to all other groups at $\mathrm{p}$ value $\leq 0.05$.

Forced swimming test: Results of forced swimming test and number of jumping for groups of different doses of reserpine were shown in Figure 2 and Figure 3. Data revealed a significant increase at $\mathrm{p}$ value $\leq 0.05$. The immobility time in all different reserpine doses $0.1 \mathrm{mg}, 0.5 \mathrm{mg}$ and $1 \mathrm{mg}$ as compared to the control group. While a significant decrease was shown in all different doses groups in number of jumping when compared the control at $p$ $\leq 0.05$.

There was a significant decrease in groups treated with different doses of reserpine $(0.1,0.5$ and $1 \mathrm{mg} / \mathrm{kg}$ body weight) in ATP contents in brain areas while the cortex ADP and brain stem AMP contents were significantly increased as compared to the control group. More over the brain stem ADP contents in mice treated with $1 \mathrm{mg} / \mathrm{kg}$ showed a significant decrease in comparison with the control group. (P value $\leq 0.05)$ as shown in (Table 2 ).

It was noticed from Figure 4 and Figure 5 there was a significant decrease in different neurotransmitters content (cortex and brain stem 5-HT, $\mathrm{NE}$ and DA) in all reserpine treated groups in comparison with control group except brain stem NE in Res 0.5 group. 
Concerning cortex and brain stem malondialdehyde (MDA) contents, there was a significant increase in MDA content in all reserpine groups when compared to the control group as shown in Table (3).

The data in Table 3 showed that there was a significant increase in cortex and brain stem, $\mathrm{NO}_{2}, \mathrm{NO}_{3}$ and $\mathrm{NO}$ in all reserpine administered mice with different doses $(0.1,0.5$ and $1 \mathrm{mg} / \mathrm{kg}$ body weight) when compared to the control group except cortex $\mathrm{NO}_{3}$ in Res 0.1 group wasn't significantly changed as compared to the control one.

There was a significant decrease in cortex and brain stem GSH and GSH/GSSG ratio. Values were reported in mice groups given different doses of reserpine in comparison to the control group ( $\mathrm{p}$ value $\leq 0.05$ ). On the contrary, there was a significant increase in cortex and brain stem GSSG in all groups given different doses in comparison with the control as showm in Table (3).

Statistical analysis of cortex and brain stem 8- hydroxyl-2deoxyguanosine (8-OHDG) contents data of mice groups administered different doses of reserpine illustrated in Figure 6. There was a significant increase in cortex and brain stem 8-OHDG in all mice treated groups as compared to the control group at $\mathrm{p} \leq 0.05$.

\section{DISCUSSION}

The mortality rate of groups given different doses of reserpine showed the highest mortality rate was in $1 \mathrm{mg} / \mathrm{kg}$ dose group while the moderate mortality was in $0.5 \mathrm{mg} / \mathrm{kg}$ dose group and the lowest mortality was in $0.1 \mathrm{mg} / \mathrm{kg}$ dose group. It was clearly noticed that the mortality percentage is 
dose dependent which means that death is directly proportional to the increase in reserpine dosage. The mechanism by which reserpine induce depression is related to depletion of CNS bioamine activity according to Tisdale and Miller (2010). The reserpine induced mortality may be attributed to severe depressive episodes associated with "high vulnerability period" during which depression increased risk of dying or having a life threatening physical conditions related to cardiovascular, respiratory or metabolic diseases like heart attacks and coronary diseases (European Society of Cardiology, 2015). Moreover, behavioral disturbances associated with depression including lack of self-care, loss of the will and motivation to live which result in severe infection, poor health and premature mortality. Rodents also share some of the factors that are influenced or altered by depression in humans, including changes in food consumption, sleep abnormalities and drug-withdrawalinduced anhedonia (Yankelevitch-Yahav et al., 2015).

In the present study, results of forced swimming test for groups of different doses of reserpine revealed significant decrease in immobility time in all different doses as compared to control group due to reserpine induced depression associated with despair and giving up and leave themselves to drowning. The result is in agreement with Huang et al. (2004); Arora and Chopra (2013) and Yankelevitch-Yahav et al. (2015). They noticed that the increase in immobility durations in the FST along with other physiological changes represented by prolonged monoamines depletion and oxidative stress. Foregoing investigations indicated that such physiological changes can persist for more than one week and thus the effectiveness of antidepressants 
could be assigned by their capability to reverse the depressive-like effects of reserpine

In the same line Bolandghamat et al. (2011) studied depression model induced by reserpine in male wistar rats and recorded a significant increase in immobility time with forced swimming test in depressed rats. Several authors reported that the results from the forced swimming test could be related to the mood state of the animal and brain levels of noradrenaline, dopamine, serotonin and cholinergic neurotransmitters (Willner, 1984). These neurotransmitters are involved in the patho physiology of some types of depression and play a permissive role in the antidepressant activities (Willner, 1995 and Ferigolo et al., 1998). The enhancement of serotonin, norepinephrine and dopamine content in the brain can reduce the immobility time of rats in the forced-swimming test (Cervo et al., 1990; Detke et al., 1995b and Calapai et al., 2001). Enhancement of dopamine and norepinephrine neurotransmission may mediate climbing in the forcedswimming test (Cervo et al., 1992; Cabib et al., 1995 and Cryan et al., 2003).

The present study demonstrated that the cortex and brain stem content of the adenyl system compounds (AMP, ADP and ATP) of groups given different doses of reserpine $(0.1,0.5$ and $1 \mathrm{mg} / \mathrm{kg}$ body weight) showed significant decrease when compared to the control group. These results are in agreement with Dias et al (2016).

Dunwiddie and Masino, (2001) investigated that the influence of reserpine upon tissue respiration and compared its effects with those of hydrallazine. A compound which interferes with cell metabolism may influence the high energy phosphate level, especially that of adenosine 
triphosphate. Decreased ATP level may be an indicator for neurodegenerative disorder results in suppression of energy in the neurons (Darby et al., 2003). Under physiological conditions, ATP is released in small amounts by astrocytes and neurons creating synaptic connections.

Reserpine is a monoamine depletor that blocks the vesicular monoamine transporter for neuronal transmission or storage, thus promoting oxidative catabolism by MAO (Lohr et al., 2003); this makes its injection a reliable model of depression in rodents (Oe et al., 2010). It's often said that depression results from a chemical imbalance, but that figure of speech doesn't capture how complex the disease is.

In the current study, there was a significant decrease in different neurotransmitters content (cortex and brain stem 5-HT, NE and DA and) in all reserpine treated groups in comparison with control group. Hall, (1998) reported that reserpine is a mono amines antagonist inducing depression to the extent that causes suicide, this theory called momoamine hypothesis. This result is coincide with Meyer et al. (2006) who stated studies of the neurobiological mechanism indicated the involvement of neurotransmitter systems in depression, showing abnormalities in the brain levels of 5-HT, NE, DA and their metabolites (Vines et al., 2012, Yu et al., 2013). The decreased brain content of 5-HT has been believed to be a core pathogenic factor in depression (Svenningsson et al., 2006).

There is preliminary evidence that an increased availability of the brain monoamine oxidase, which metabolizes serotonin, may cause serotonin deficiency. In addition, loss-of-function mutations in the gene coding for the 
brain-specific enzyme tryptophan hydroxylase-2 may explain the loss of serotonin production as a rare risk factor for depression (Hasler, 2010).

Concerning cortex and brain stem malondialdehyde (MDA) in the present study, there was a significant increase in MDA in all reserpine groups when compared to control group. In support of the present results, Chang et al. (2010) stated that increased MDA contents in depressed patients due to increased oxidative stress (Kurien and Scofield, 2006 and Mansour et al., 2008).

Moreover, Michel et al. (2012) reported that modern imaging techniques show volume reduction of the hippocampus and the frontal cortex associated with depressive episodes. Cytochrome c release can increase free radical production by the mitochondrial electron transport chain causing non-specific cellular damage and necrotic-like morphology (Murphy et al., 1999). Depending on the levels of cytochrome c released by mitochondria, the amount of ATP may be insufficient to complete the apoptotic program. Because of this, cells can die by apoptosis or necrosis (Bonfoco et al., 1995). These results are in line with post-mortem studies of patients with depressive disorder. They point to a significant decrease of neuronal and glial cells in cortico-limbic regions which can be seen as a consequence of alterations in neuronal plasticity in this disorder. This could be triggered by an increase of free radicals which in turn eventually leads to cell death and consequently atrophy of vulnerable neuronal and glial cell population in these regions. Therefore, research on increased oxidative stress in unipolar depressive disorder, mediated by elevated concentrations of free radicals, has been undertaken. 
In the present study, a significant decrease in cortex and brain stem glutathione (GSH) values and its oxidized form (GSSG) was reported in all groups given different doses of reserpine $(0.1,0.5$ and $1 \mathrm{mg} / \mathrm{kg}$ body weight respectively) in comparison to control group. These results are parallel with Maes et al. (2011) who reported low level of glutathione and glutathione peroxidase associated with depression.

Glutathione it is a major endogenous free radical scavenger and its reduction can increase vulnerability to cellular oxidative stress (Berk et al., 2008). There is evidence that patients with depression have decreased antioxidant capacity in plasma as shown by lowered levels of glutathione peroxidase . Also a post-mortem study of prefrontal cortex in brain tissue, derived from the Stanley Foundation Consortium, found lowered levels of both GSH and GPX (Maes et al., 2011).

Schulz et al. (2000) reported that there is significant evidence in the pathogenesis of several neurodegenerative diseases, including Parkinson's disease, depression, Alzheimer's disease, Friedreich's ataxia and amyotrophic lateral sclerosis, may involve the generation of reactive oxygen species and mitochondrial dysfunction. Also there is evidence for a disturbance of glutathione homeostasis that may either lead to or result from oxidative stress in neurodegenerative disorders (Halliwell, 2006 and Reynolds et al., 2007). Glutathione is an important intracellular antioxidant that protects against a variety of different antioxidant species. An important role for glutathione was proposed for the pathogenesis of Parkinson's disease, because a decrease in total glutathione concentrations in the substantia nigra has been observed in 
preclinical stages (Gawryluk et al., 2011) at a time at which other biochemical changes are not yet detectable. Because glutathione does not cross the blood-brain barrier other treatment options to increase brain concentrations of glutathione including glutathione analogs, mimetics or precursors are discussed (Sting et al., 2005).

There was a significant increase in cortex and brain stem $\mathrm{NO}_{2}, \mathrm{NO}_{3}$ and NO in all reserpine administered mice with different doses $(0.1,0.5$ and 1 $\mathrm{mg} / \mathrm{kg}$ body weight) compared to control group. The present finding is in agreement with Dhir and Kulkarni (2011) who reported that Nitric oxide has been known to play a significant role in the pathophysiology of various disorders of the body. Despite its very short half-life, nitric oxide is known to modulate various neurotransmitter system(s) in the body. It is speculated to play an imperative role in the pathogenesis of neurological disorders. This "wonder" molecule has been often found to possess a "dual role" in many neurological disorders of the body. Dysregulation of the nitrergic system has been well documented in depression (Bernstein et al., 2005; Kim et al., 2006 and Oliveira et al., 2008).

Evidences have shown its prominent role in the pathogenesis of major depression. Nitric oxide modulates norepinephrine, serotonin, dopamine, glutamate, the major neurotransmitters involved in the neurobiology of major depression. Accumulate Nitric oxide (NO) evidence supports the hypothesis that it plays a critical role in neuro-degenerative disorders (Bogdan, 2001).

Statistical analysis of cortex and brain stem 8- hydroxyl-2deoxyguanosine (8-OHDG) data of mice groups administered different doses of reserpine revealed significant increase in cortex and brain stem (8-OHDG) 
in mice groups administered with different doses of reserpine as compared to the control group. This result is coincide with Aitken and De Iuliis (2010) who reported that (8OHDG) formation and DNA fragmentation were highly correlated with each other and frequently associated with cell death. 8hydroxyl-2-deoxyguanosine (8-OHDG) is a biomarker of systemic oxidative DNA damage and its level increased with clinical depression (Siyan et al., 2012). The central nervous system is highly vulnerable to damage from oxidative stress; 8-hydroxylated guanine species such as 8-oxoguanine and 8OHDG are repair products of oxidized guanine lesions. Previous studies linking increased concentrations of 8-OHDG to increased oxidative stress or disease states (Arnett et al., 2005 and Arunachalam et al., 2015)

Table (1): Showing mortality rate of mice groups $(n=15)$ given different doses of reserpine:

\begin{tabular}{|c|c|c|c|c|}
\hline $\begin{array}{c}\text { Resepine } \\
\text { Concentration }\end{array}$ & $\begin{array}{c}\text { Number } \\
\text { of Mice }\end{array}$ & $\begin{array}{c}\text { Number of } \\
\text { Survive Mice }\end{array}$ & $\begin{array}{c}\text { Number of } \\
\text { Mortality Mice }\end{array}$ & $\begin{array}{c}\text { \% of } \\
\text { MortalityMice }\end{array}$ \\
\hline Con & 15 & 15 & 0 & $0 \%$ \\
\hline Res 0.1 & 15 & 14 & 1 & $6.7 \%$ \\
\hline Res 0.5 & 15 & 7 & 8 & $53.3 \%$ \\
\hline Res 1 & 15 & 4 & 11 & $73.3 \%$ \\
\hline
\end{tabular}


Table (2): Showing cortex and brain stem Adinosine monophosphate (AMP) content, adenosine Diphosphate (ADP) content and Adenosine triphosphate (ATP) content, (ug/g) of different treated groups.

\begin{tabular}{|c|c|c|c|c|}
\hline $\begin{array}{c}\text { Brian } \\
\text { area }\end{array}$ & $\begin{array}{c}\text { Parameter } \\
\text { Groups }\end{array}$ & AMP & ADP & ATP \\
\hline \hline \multirow{4}{*}{ Cortex } & Control & $7.199 \pm 0.452$ & $10.53 \pm 0.596$ & $31.317 \pm 1.000$ \\
\cline { 2 - 5 } & Res 0.1 & $6.101 \pm 0.323^{\mathrm{a}}$ & $18.31 \pm 0.138^{\mathrm{a}}$ & $17.03 \pm 0.300^{\mathrm{a}}$ \\
\cline { 2 - 5 } & Res 0.5 & $6.146 \pm 0.149^{\mathrm{a}}$ & $17.67 \pm 0.301^{\mathrm{a}}$ & $13.53 \pm 0.240^{\mathrm{ab}}$ \\
\cline { 2 - 5 } & Res 1 & $6.015 \pm 0.242^{\mathrm{a}}$ & $11.32 \pm 0.421^{\mathrm{bc}}$ & $18.09 \pm 0.667^{\mathrm{ac}}$ \\
\hline \multirow{4}{*}{$\begin{array}{c}\text { Brain } \\
\text { Stem }\end{array}$} & Control & $9.432 \pm 0.276$ & $17.57 \pm 0.563$ & $30.39 \pm 1.691$ \\
\cline { 2 - 5 } & Res 0.1 & $12.15 \pm 0.774^{\mathrm{a}}$ & $16.47 \pm 1.180$ & $22.69 \pm 1.111^{\mathrm{a}}$ \\
\cline { 2 - 5 } & Res 0.5 & $12.18 \pm 0.625^{\mathrm{a}}$ & $16.08 \pm 0.583$ & $17.65 \pm 1.363^{\mathrm{ab}}$ \\
\cline { 2 - 5 } & Res 1 & $12.49 \pm 0.347^{\mathrm{a}}$ & $15.20 \pm 0.836^{\mathrm{a}}$ & $17.55 \pm 0.557^{\mathrm{ab}}$ \\
\hline \hline
\end{tabular}

Values are means of 8 mice \pm SE at $(\mathrm{P}<0.05)$, $a=$ significant change from control, $b=$ significant from Res 0.1 and c=significant from Res $0.5 \mathrm{mg} / \mathrm{kg}$. 
Table (3): Effect of different doses of reserpine on cortex and brain stem NO, (umole/g), MDA, (nmole/g), GSH, GSSG and GSH/GSSG ratio, (umole/g)

\begin{tabular}{|c|c|c|c|c|c|c|c|c|}
\hline \multirow{2}{*}{$\begin{array}{c}\text { Brian } \\
\text { area }\end{array}$} & \multirow[b]{2}{*}{ Groups } & \multicolumn{7}{|c|}{ Parameter } \\
\hline & & $\mathrm{NO}_{2}$ & $\mathrm{NO}_{3}$ & NO & MDA & GSH & GSSG & $\begin{array}{l}\text { GSH/ } \\
\text { GSSG }\end{array}$ \\
\hline \multirow{8}{*}{ Cortex } & \multirow{2}{*}{ Control } & $0.447 \pm$ & $0.147 \pm$ & $0.595 \pm$ & $14.51 \pm$ & $10.34 \pm$ & $0.558 \pm$ & $18.60 \pm$ \\
\hline & & 0.036 & 0.025 & 0.055 & 0.736 & 0.239 & 0.012 & 0.68 \\
\hline & \multirow{2}{*}{ Res 0.1} & $0.833 \pm$ & $0.155 \pm$ & $0.988 \pm$ & $28.63 \pm$ & $6.265 \pm$ & $1.048 \pm$ & $6.00 \pm$ \\
\hline & & $0.033^{a}$ & 0.021 & $0.038^{\mathrm{a}}$ & $0.343^{\mathrm{a}}$ & $0.299^{\mathrm{a}}$ & $0.023^{\mathrm{a}}$ & $0.33^{a}$ \\
\hline & \multirow{2}{*}{ Res 0.5} & $0.872 \pm$ & $0.239 \pm$ & $1.110 \pm$ & $30.24 \pm$ & $6.198 \pm$ & $1.786 \pm$ & $3.46 \pm$ \\
\hline & & $0.030^{a}$ & $0.033^{a b}$ & $0.030^{a b}$ & $0.602^{\mathrm{ab}}$ & $0.335^{\mathrm{a}}$ & $0.026^{\mathrm{ab}}$ & $0.16^{\mathrm{ab}}$ \\
\hline & \multirow{2}{*}{ Res 1} & $0.899 \pm$ & $0.250 \pm$ & $1.148 \pm$ & $29.72 \pm$ & $6.261 \pm$ & $1.664 \pm$ & $3.77 \pm$ \\
\hline & & $0.022^{\mathrm{a}}$ & $0.021^{a b}$ & $\mathbf{0 . 0 3 3}^{\mathrm{ab}}$ & $0.394^{\mathrm{a}}$ & $0.364^{\mathrm{a}}$ & $0.045^{\mathrm{abc}}$ & $0.22^{\mathrm{ab}}$ \\
\hline \multirow{8}{*}{ 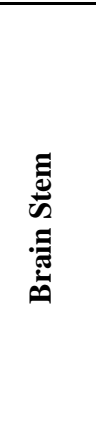 } & \multirow{2}{*}{ Control } & $0.762 \pm$ & $0.262 \pm$ & $1.025 \pm$ & $10.62 \pm$ & $21.45 \pm$ & $0.664 \pm$ & 32.30 \pm \\
\hline & & 0.029 & 0.021 & 0.033 & 0.074 & 1.196 & 0.039 & 1.44 \\
\hline & \multirow{2}{*}{ Res 0.1} & $0.892 \pm$ & $0.870 \pm$ & $1.763 \pm$ & $15.06 \pm$ & $10.26 \pm$ & $1.421 \pm$ & $7.51 \pm$ \\
\hline & & $0.038^{a}$ & $0.037^{\mathrm{a}}$ & $0.076^{\mathrm{a}}$ & $0.258^{\mathrm{a}}$ & $0.524^{\mathrm{a}}$ & $0.108^{\mathrm{a}}$ & $0.67^{\mathrm{a}}$ \\
\hline & \multirow{2}{*}{ Res 0.5} & $0.897 \pm$ & $0.864 \pm$ & $1.736 \pm$ & $14.00 \pm$ & 23.71 \pm & $0.621 \pm$ & $38.85 \pm$ \\
\hline & & $0.037^{\mathrm{a}}$ & $0.048^{\mathrm{a}}$ & $0.085^{\mathrm{a}}$ & $0.597^{a b}$ & $2.109^{b}$ & $0.033^{b}$ & $4.14^{b}$ \\
\hline & \multirow{2}{*}{ Res 1} & $0.902 \pm$ & $0.858 \pm$ & $0.723 \pm$ & $15.04 \pm$ & $22.54 \pm$ & $0.611 \pm$ & $37.36 \pm$ \\
\hline & & $0.030^{a}$ & $0.032^{\mathrm{a}}$ & $0.066^{\mathrm{a}}$ & $0.344^{\mathrm{ac}}$ & $1.764^{b}$ & $0.052^{b}$ & $2.00^{b}$ \\
\hline
\end{tabular}

Values are means of 8 mice \pm SE at $(\mathrm{P}<0.05)$, a = significant change from control, $b=$ significant from Res 0.1 and c=significant from Res $0.5 \mathrm{mg} / \mathrm{kg}$. 


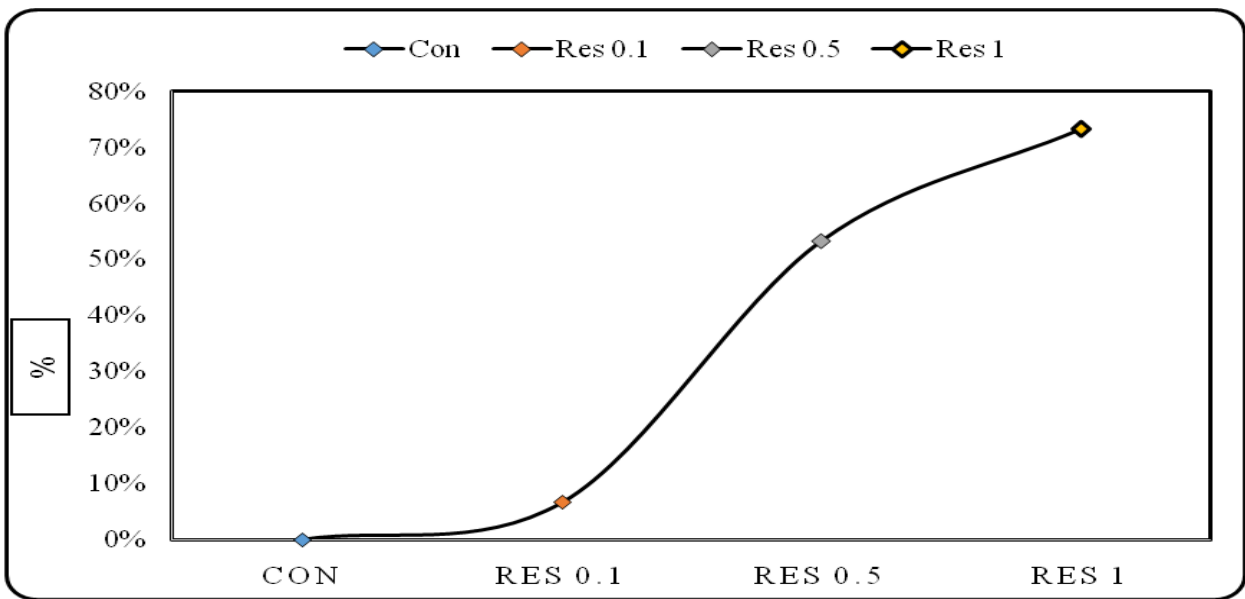

Figure (1): Showing mortality rate of mice groups given different doses of reserpine $(0.1,0.5$ and $1 \mathrm{mg} / \mathrm{kg})$. Values are means of 8 mice \pm $\mathrm{SE}$ at $(\mathrm{P}<0.05)$.

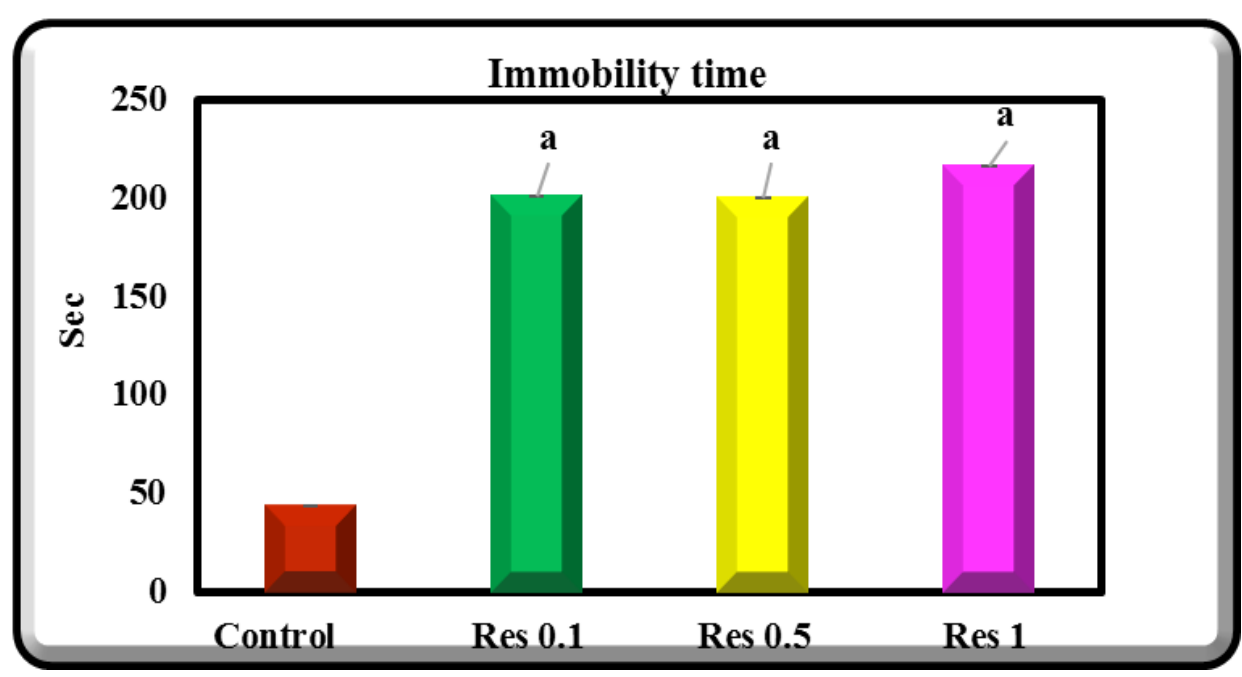

Figure (2): Showing immobility time (seconds) of groups treated with reserpine doses $(0.1,0.5,1 \mathrm{mg} / \mathrm{kg})$. Values are means of 8 mice \pm $\mathrm{SE}$ at $(\mathrm{P}<0.05), \mathrm{a}=$ significant change from control.

Vol. 36, No.1, Dec. 2016 


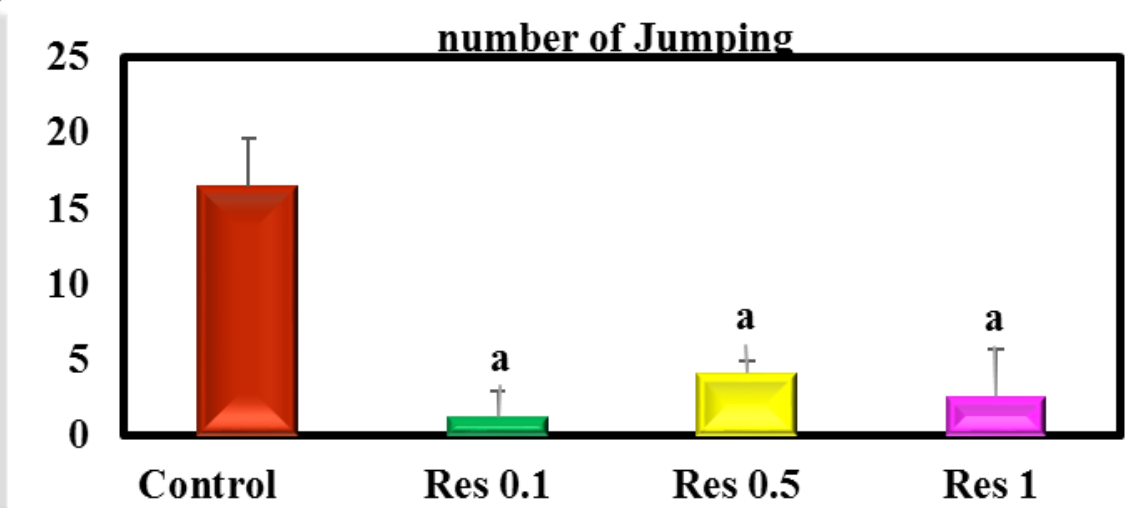

Figure (3): Showing number of Jumping of groups treated with reserpine doses $(0.1,0.5,1 \mathrm{mg} / \mathrm{kg})$. Values are means of 8 mice $\pm \mathrm{SE}$ at $(\mathrm{P}<0.05), \mathrm{a}=$ significant change from control.

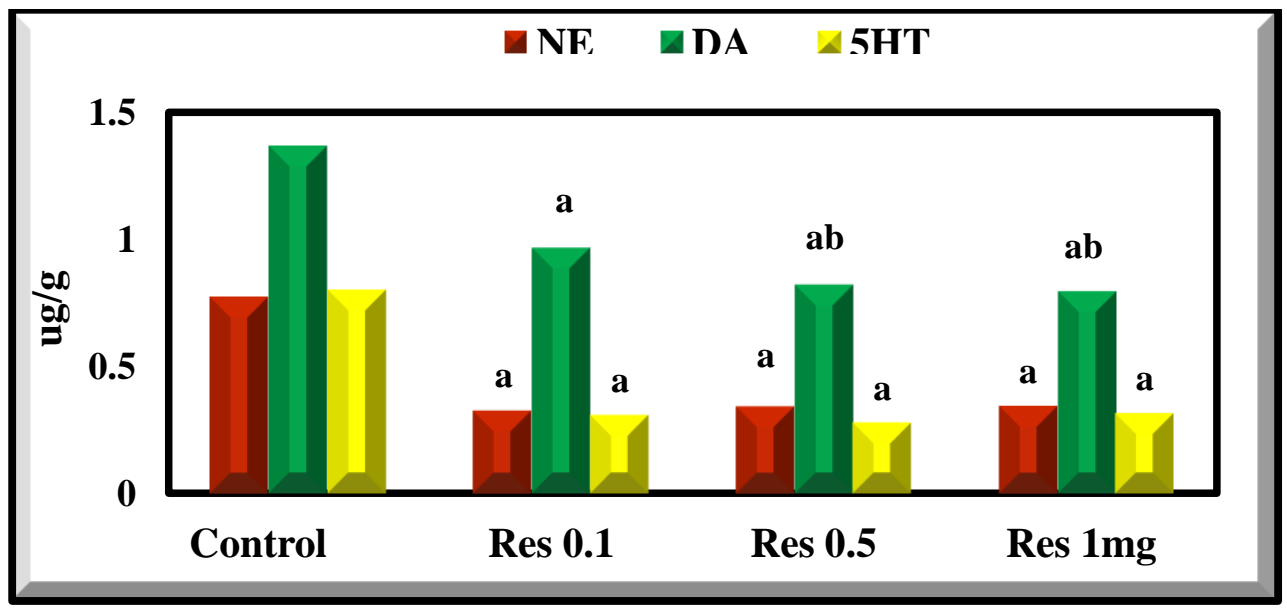

Figure (4): Effect of different doses of reserpine on cortex neurotransmitters (NE, DA and 5HT), (ug/g). Values are means of 8 mice $\pm \mathrm{SE}$ at $(\mathrm{P}<0.05), a=$ significant change from control and $\mathrm{b}=$ significant from Res $0.1 \mathrm{mg} / \mathrm{kg}$. 


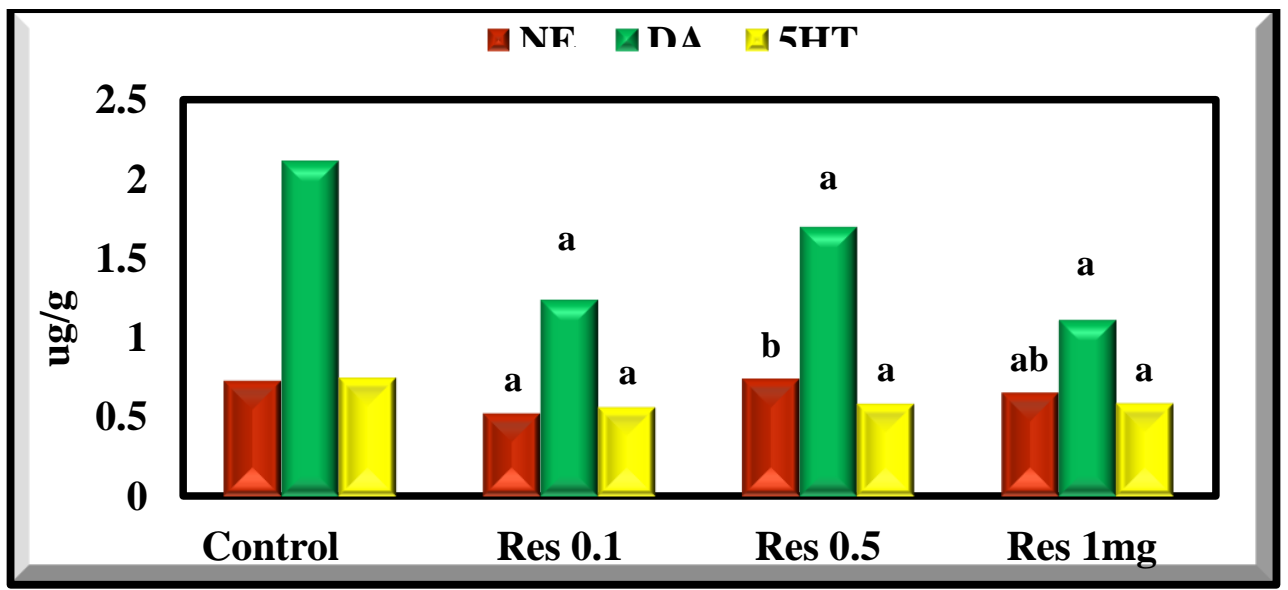

Figure (5): Effect of different doses of reserpine on brain stem neurotransmitters (NE, DA) and 5HT) (ug/g). Values are means of 8 mice $\pm \mathrm{SE}$ at $(\mathrm{P}<0.05)$, a=significant change from control and $b=$ significant from Res 0.1 .

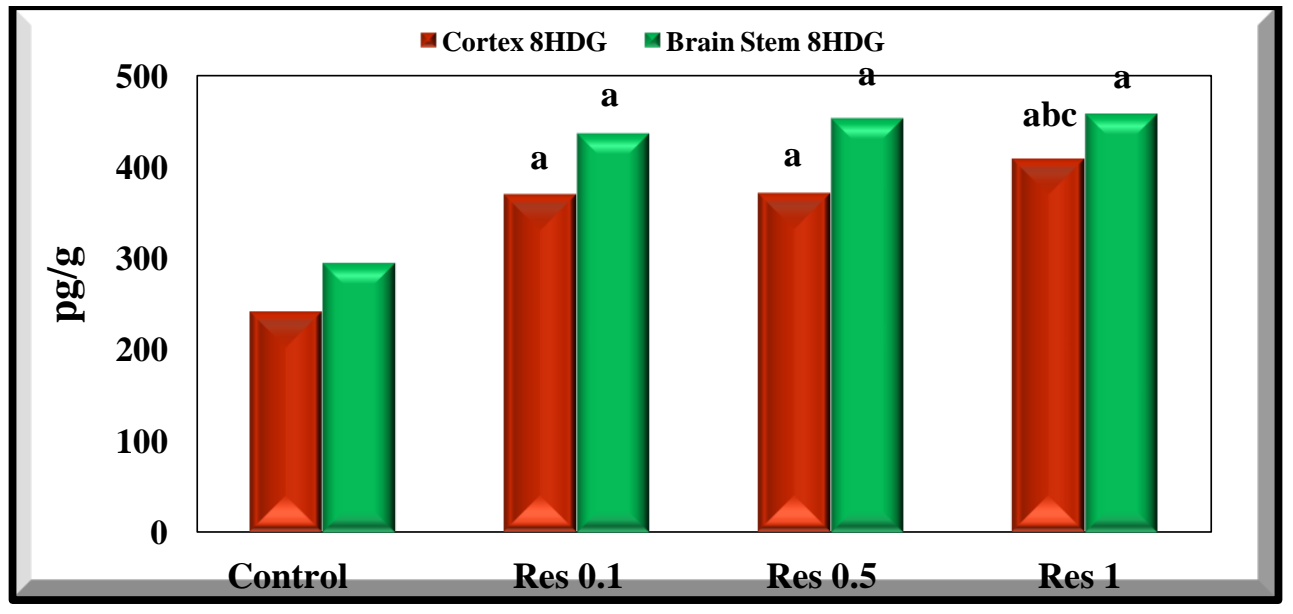

Figure (6): Shows effect of different doses of reserpine on cortex and brain stem $(8-\mathrm{OHDG}),(\mathrm{pg} / \mathrm{g})$. Values are means of 8 mice $\pm \mathrm{SE}$ at $(\mathrm{P}<0.05), a=$ significant change from control, $\mathrm{b}=$ significant from Res 0.1 and c=significant from Res $0.5 \mathrm{mg} / \mathrm{kg}$. 
J. Environ. Sci.

Institute of Environmental Studies and Research - Ain Shams University

\section{CONCLUSION}

The present study suggested that the small used dose of reserpine $(0.1$ $\mathrm{mg} / \mathrm{kg}$ ) is the most suitable dose for induction of depression with the less mortality rate and the same effect on the brain monoamines contents.

\section{REFERENCE}

Abílio, V. C.; Araujo, C. S.; Bergamo, M.; Calvente, P. R.; D’Almeida, V.; Ribeiro, R. A. and Frussa-Filho, R. (2003): Vitamin E attenuates reserpine-induced oral dyskinesia and striatal oxidized glutathione/reduced glutathione ratio (GSSG/GSH) enhancement in rats. Progress in Neuro-Psychopharmacology and Biological Psychiatry, 27: 109-114.

Aitken, R. J. and De Iuliis, G. N. (2010): On the possible origins of DNA damage in human spermatozoa. Molecular Human Reproduction, 16: $3-13$.

Arnett, S.; Osbourn, D.; Moore, K.; Vandaveer, S. and Lunte, C. (2005): Determination of 8-oxoguanine and 8-hydroxy-2'deoxyguanosine in the rat cerebral cortex using microdialysis sampling and capillary electrophoresis with electrochemical detection. The Journal of Chromato- graphy B Analytical Technologiesin the Biomedical and Life Sciences, 827: $16-25$.

Arora, V. and Chopra, K. (2013): Possible involvement of oxido nitrosative stress induced neuro-inflammatory cascade and monoaminergic pathway: underpinning the correlation between nociceptive and depressive behaviour in a rodent model. Journal of Affective Disorders, 151: 1041-1052.

Arunachalam, R.; Reshma, A. P.; Rajeev, V.; Kurra, S. B.; Prince, R. J. and Syam, N. (2015): Salivary 8-Hydroxydeoxyguanosine - a valuable indicator for oxidative DNA damage in periodontal disease. The Saudi Journal for Dental Research, 6: 15-20. 
Berk, M.; Copolov, D. L.; Dean, O.; Lu, K.; Jeavons, S.; Schapkaitz, I.; Anderson-Hunt, M. and Bush, A. I. (2008): N-acetyl cysteine for depressive symptoms in bipolar disorder a double-blind randomized placebo-controlled trial. Biological Psychiatry, 64: $468-475$.

Bernstein, H. G.; Heinemann, A.; Krell, D.; Dobrowolny, H.; Bielau, H.; Keilhoff, G. and Bogerts, B. (2005): Hypothalamic nitric oxide synthase in affective disorder: focus on the suprachiasmatic nucleus. Cellular and Molecular Biology (Noisy-le-Grand, France). 51: 279-284.

Bilska, A.; Dubiel, M.; Sokołowska-Jezewicz, M.; Lorenc-Koci, E. and Włodek, L. (2007): Alpha-lipoic acid differently affects the reserpine-induced oxidative stress in the striatum and prefrontal cortex of rat brain. Neuroscience, 146: 17581771.

Bogdan, C. (2001): Nitric oxide and the immune response. Nature Immunology, 2: 907-916.

Bolandghamat, S.; Moghimi, A. and Ranshahi, M. (2011): Effects of ethanolic extract of pine needles (PinuseldaricaMedw) on reserpine-induced depression-like behavior in male Wistar rats. Pharmacognosy Magazine, 27: 248-253.

Bonfoco, E.; Krainc, D.; Ankarcrona, M.; Nicotera, P. and Lipton, S. A. (1995): Apoptosis and necrosis: two distinct events induced, respectively, by mild and intense insults with N-methyl-Daspartate or nitric oxide/superoxide in cortical cell cultures. Proceedings of the National Academy of Sciences, 92: 71627166.

Bulaj, G.; Kortemme, T. and Goldenberg, D. P. (1998): Ionization reactivity relationships for cysteine thiols in polypeptides. Biochemistry, 37: 8965-8972.

Cabib, S.; Zocchi, A. and Puglisi-Allegra, S. (1995): A comparison of the behavioral effects of minaprine, amphetamine and stress. Psychopharmacology (Berl), 121: 73-80. 
Calapai, G.; Crupi, A.; Firenzuoli, F.; Inferrera, G.; Squadrito, F.; Parisi, A.; De Sarro, G. and Caputi, A. (2001): Serotonin, norepinephrine and dopamine involvement in the antidepressant action of hyperi cumperforatum. Pharmacopsychiatry, 34: 45-49.

Cervo, L. Grignaschi, G. and Samanin, R. (1990): The role of the mesolimbic dopaminergic system in the desipramine effect in the forcedswimming test. European Journal of Pharmacology, 178: 129133.

Cervo, L.; Rossi, C. and Samanin, R. (1992): The role of serotonin and dopamine in the brain in the antidepressant-like effect of clonidine in the forced-swimming test. Neuropharmacology, 31: $331-335$.

Chang, Y.; Liu, Y. and Liu, C. (2010): The Effect on Serotonin and MDA Levels in Depressed Patients with Insomnia when Far-Infrared Rays are Applied to Acupoints. The American Journal of Chinese Medicine, 37: 837-842.

Croy, I.; Symmank, A.; Schellong, J.; Hummel, C.; Gerber, J.; Joraschky, P. and Hummel, T. (2014): 'Olfaction as a marker for depression in humans'. Journal of affective disorders, 160: 80-86.

Cryan, J. F.; Hoyer, D. and Markou, A. (2003): Withdrawal from chronic amphetamine induces depressive-like behavioral effects in rodents. Biological Psychiatry, 54: 49-58.

Darby, J.; Kuzmiski, B.; Panenka, W.; Feighan, D. and MacVicar, A. (2003): ATP Released From Astrocytes During Swelling Activates Chloride Channels Mark. Neurophysiol, 89: 1870-1877.

Detke, M. J.; Rickels, M. and Lucki, I. (1995): Active behaviors in the rat forced-swimming test differentially produced by serotonergic and noradrenergic antidepressants. Psychopharmacol, 121: 66-72.

Dhir, A. and Kulkarni, S. K. (2011): Nitric oxide and major depression. Nitric Oxide, 24: 125-131. 
Dias, K. C.; Patrocínio, C. F.; Barroso, P. L.; Rodrigues, R. B.; Nascimento, P. A.; Medeiros, I. S.; Júnior, J. E.; de Sousa, C. N.; Patrocinio, M. C. and Vasconcelos, S. M. (2016): Alpha-Lipoic Acid Effects on Reserpine-Induced DepressionLike Behavior in Mice. JSM Anxiety Depression, 1: 1010-1016.

Dong, L.; Wenping, L.; Zhou, X.; Kang, Q. and Shen, W. (2009): "Liquid liquid extraction of matrine using TRPO/cyclohexane reverse micelles" Brazilian Journal of Chemical Engineering, 26: 2-8.

Dunwiddie, T. V. and Masino, S. A. (2001): The role and regulation of adenosine in the Central Nervous System. Annual Review of Neuroscience, 24: 31-55.

Ellman, G. L. (1959): Tissue sulfhydryl groups. Archives of biochemistry and biophysices, 82: 70-77.

European Society of Cardiology (ESC) (2015): Depression associated with 5fold increased mortality risk in heart failure patients.

Ferigolo, M.; Barros, H. M. T.; Marquardt, A. R. and Tannhauser, M. (1998): Comparison of behavioral effects of meclobemide and deprenyl during forced-swimming. Pharmacology Biochemistry and Behavior, 60: 431-437.

Freitas, C. M.; Busanello, A.; Schaffer, L. F.; Peroza, L. R.; Bárbara, N. K.; Leal, Q. C.; Chiapinotto, A. C.; Da Rocha, J. T. and Fachinetto, R. (2016): Behavioral and neurochemical effects induced by reserpine in mice. Psychopharmacology, 233: 457-467.

Gawryluk, J. W.; Wang, J. F.; Andreazza, A. C.; Shao, L. and Young, L. T. (2011): Decreased levels of glutathione, the major brain antioxidant, in post-mortem prefrontal cortex from patients with psychiatric disorders. International Journal of Neuropsychopharmacology, 14: 123-130.

Gotlib, I. H. and Joormann, J. (2010): Cognition and Depression: Current Status and Future Directions. Annual Review of Clinical Psychology, 6: 285-312.

Hall, R. H. (1998): Theories of Depression. 
Halliwell, B. (2006): Reactive species and antioxidants. Redox biology is a fundamental theme of aerobic life. Plant Physiology, 141: 312322.

Hasler, G. (2010): Pathophysiology of depression: do we have any solid evidence of interest to clinicians. World Psychiatry, 9: 155-161.

Henry, J. P.; Sagne, C.; Botton, D.; Isambert, M. F. and Gasnier, B. (1998): Molecular pharma-cology of the vesicular monoamine transporter. Advances in Pharmacology, 42: 236-245.

Huang, Q. J.; Jiang, H.; Hao, X. L. and Minor, T. R. (2004): Brain IL-1 beta was involved in reserpine-induced behavioral depression in rats. Acta Pharmacologica Sinica, 25: 293-296.

Hurley, L. L.; Akinfiresoye, L.; Kalejaiye, O. and Tizabi, Y. (2014): Antidepressant effects of resveratrol in an animal model of depression. Behavioural Brain Research, 268: 1-7.

Kim, Y. K.; Paik, J. W.; Lee, S. W.; Yoon, D.; Han, C. and Lee, B. H. (2006): Increased plasma nitric oxide level associated with suicide attempt in depressive patients. Progress in NeuroPsychopharmacology and Biological Psychiatry, 30: 10911096.

Kurien, B. T. and Scofield, R. H. (2006): Lipid peroxidetion in systemic lupus erythematosus. Indian Journal of Experimental Biology, 44: 349-356.

Leith, N. J. and Barrett, R. J. (1980): Effect of chronic amphetamine or reserpine on self-stimulation responding: animal model of depression. Psychopharmacology (Berl), 72: 9-15.

Liu, H.; Jiang, Y.; Luo, Y. and Jiang, W. A. (2006): Simple and Rapid Determination of ATP, ADP and AMP Concentrations in Pericarp Tissue of Litchi Fruit by High Performance Liquid Chromatography, Food Technology and Biotechnology, 44: 531534. 
Lodovici, M.; Casalini, C. Briani, C. and Dolara, P. (1997): Oxidative liver DNA damage in rats treated with pesticide mixtures. Toxicology, 117: 55-60.

Lohr, J. B.; Kuczenski, R. and Niculescu, A. B. (2003): Oxidative mechanisms and tardive dyskinesia. Central Nervous System Drugs, 17: 47-62.

Maes, M.; Mihaylova, I.; Kubera, M.; Uytterhoeven, M.; Vrydags, N. and Bosmans, E. (2011): Lower whole blood glutathione peroxidase (GPX) activity in depression, but not in myalgic encephalomyelitis / chronic fatigue syndrome: another pathway that may be associated with coronary artery disease and neuroprogression in depression. Neuro EndocrinolLett, 32: 133140 .

Mansour, R. B.; Lassoued, S.; Gargouri, B.; El Gaid, A.; Attia, H. and Fakhfakh, F. (2008): Increased levels of autoantibodies against catalase and superoxide dismutase associated with oxidative stress in patients with rheumatoid arthritis and systemic lupus erythematosus. Scandi- navian Journal of Rheumatology, 37: 103108.

Meyer, J. H.; Ginovart, N.; Boovariwala, A.; Sagrati, S.; Hussey, D.; Garcia, A.; Young, T.; Praschak-Rieder, N.; Wilson, A. A.; Houle, S. (2006): Elevated monoamine oxidase a levels in the brain: an explanation for the monoamine imbalance of major depression. Archives of General Psychiatry, 63: 1209-1216.

Michel, T. M.; Pülschen, D. and Thome, J. (2012): The Role of Oxidative Stress in Depressive Disorders, Current pharmaceutical design, 18: 5890-5899.

Murphy, A. N.; Fiskum, G. and Beal, M. F. (1999): Mitochondria in neurodegeneration: bioenergetic function in cell life and death. The Journal of Cerebral Blood Flow and Metabolism, 19: 231245.

Oe, T.; Tsukamoto, M. and Nagakura, Y. (2010): Reserpine causes biphasic nociceptive sensitivity alteration in conjunction with brain biogenic amine tones in rats. Neuroscience, 169: 1860-1871. 
Oliveira, R. M.; Guimaraes, F. S. and Deakin, J. F. (2008): Expression of neuronal nitric oxide synthase in the hippocampal formation in affective disorders. Brazilian Journal of Medical Biological Research, 41: 333-341.

Pagel, P.; Blome, J. and Wolf, H. U. (2000): High-performance liquid chromatographic separation and measurement of various biogenic compounds possibly involved in the pathomechanism of Parkinson's disease. Journal Chromatography Biomedical Sciences Application, 746: 297-304.

Papadoyannis, L.; Samanidou, V. and Nitsos, C. (1999): Simultaneous determination of nitrite and nitrate in drinking water and human serum by high performance anion-exchange chromatography and UV detection. Journal of Liquid Chromatography and Related Technologies, 22: 2023-2041.

Porcelli, S.; Drago, A.; Fabbri, C. and Serretti, A. (2011): Mechanisms of antidepressant action: an integrated dopaminergic perspective. Progress in Neuro-Psychopharmacology and Biological Psychiatry, 35: 1532-1543.

Porsolt, R. D.; Bertin, A. and Jalfre, M. (1977): Behavioral despair in mice: a primary screening test for antidepressants. Archives Internationales Pharmacodynamie et de Therapie, 229: 327-336.

Ranganath, D. and Raj, M. A. (2015): Studies on Extraction Behaviour of Reserpine during Reverse Micellar Extraction from Rauwolfia Vomitoria International Journal of Innovative Research in Science, 4: $2347-2355$.

Ranganath, D.; Gajendra, A.; Clyde, S. and Silva, D. (2013). "Extraction of Reserpine from Raoulfia vommotoria" students project, International Journal of Innovative Research in Science, 4: 3-9.

Reynolds, A.; Laurie, C.; Mosley, R. L. and Gendelman, H. E. (2007): Oxidative stress and the pathogenesis of neurodegenerative disorders. International review of neurobiology, 82: 297-325. 
Ruiz-Larrea, M. B.; Leal, A. M.; Liza, M.; Lacort, M. and De Groot, H. (1994): Antioxidant effects of estradiol and 2-hydroxyestradiol on iron-induced lipid peroxidation of rat liver microsomes. Steroids, 59: 383-388.

Schulz, J. B.; Lindenau, J.; Seyfried, J. and Dichgans, J. (2000): Glutathione, oxidative stress and neurodegeneration. European Journal of Biochemistry, 267: 4904-4911.

Siyan, Y.; Nanri, A.; Matsushita, Y.; Kasai, H.; Kawai, K. and Mizoue, T. (2012): Depressive symptoms and oxidative DNA damage in Japanese municipal employees. Psychiatry Research, 200: 318322.

Sting, 1. J.; Emerman, J. T. and Eaves, C. J. (2005): Enzymatic dissociation and culture of normal human mammary tissue to detect progenitor activity. Methods in molecular biology, 290: 249-263.

Svenningsson, P.; Chergui, K.; Rachleff, I.; Flajolet, M.; Zhang, X.; El Yacoubi, M.; Vaugeois, J. M.; Nomikos, G. G. and Greengard, P. (2006): Alterations in 5-HT1B receptor function by $\mathrm{p} 11$ in depression-like states. Science, 311: 77-80.

Thakare, V. N. and Patel, B. M. (2015): Potential targets for the development of novel antidepressants: future perspectives. CNS Neurol Disord Drug Targets, 14: 270-281.

Tisdale, J. E. and Miller, D. A. (2010): Drug-Induced Diseases: Prevention, Detection, and Management. American Society of health System pharmacist, 2: 333-343.

Vines, A.; Delattre, A. M.; Lima, M. M.; Rodrigues, L. S.; Suchecki, D.; Machado, R. B.; Tufik, S.; Pereira, S. I.; Zanata, S. M. and Ferraz, A. C. (2012): The role of 5-HT (1) A receptors in fish oilmediated increased BDNF expression in the rat hippocampus and cortex: a possible antidepressant mechanism. Neuropharmacology, 62: 184-191.

Willner, P. (1984): The validity of animal models of depression. Psychopharmacology (Berl), 83: 1-16. 
Willner, P. (1995): Dopaminergic mechanisms in depression and mania. In F. E. Bloom and D. J. Kupfer (eds) Psychopharmacology, Raven Press, 921-932.

Willner, P.; Scheel-Krüger, J. and Belzung, C. (2013): The neurobiology of depression and antidepressant action. Neuroscience and Biobehavioral Reviews, 37: 2331-2371.

Yankelevitch-Yahav, R.; Franko, M.; Huly, A. and Doron, R. (2015): The forced swim test as a model of depressive-like behavior, 10: 3791-3799.

Yu, Y.; Wang, R.; Chen, C.; Du, X.; Ruan, L.; Sun, J.; Li, J.; Zhang, L.; O'Donnell, J. M. and Pan, J. (2013): Antidepressant-like effect of trans-resveratrol in chronic stress model: behavioral and neurochemical evidences. Journal of Psychiatric Research, 47: 315-322.

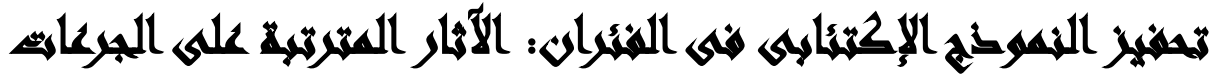

\section{(1)}

[1]

$$
\text { عفاف أبو نور (')- إلهام على (')- عمر أحمد فريد(r) - بارقة أبو خزام }
$$

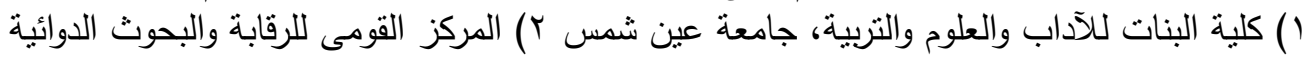

\section{المستيلت}

يعرف الاكتئاب باضطراب المزاج الذي تشمل خصائصه انخفاض الحركة بصورة دائمة وانخفاض قدرة تحفيز وبطء وظائف التفكير والإدراك. وقد أظهرت إحدى الدراسات المحلية أن معدل

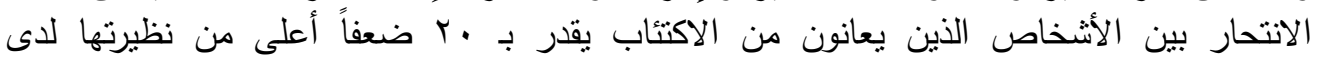

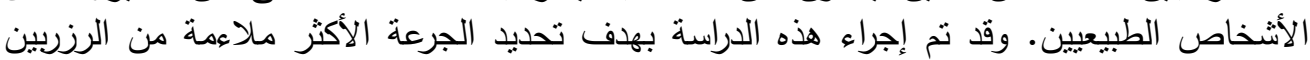

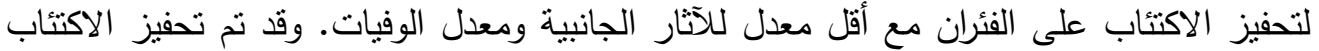

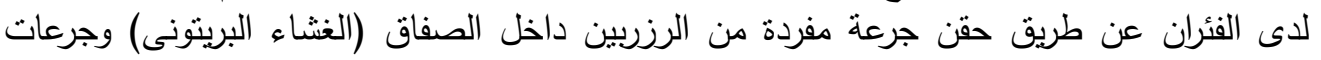

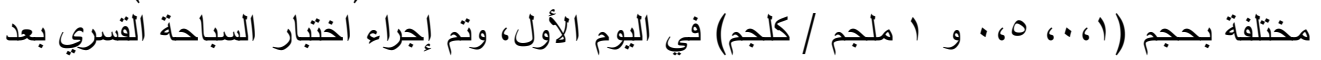

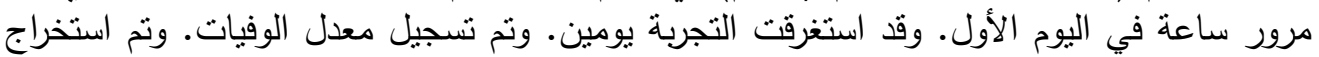
المخ وتجهيزه لتحديد محتوى الأدينوسين أحادى الفوسفات، الأدينوسين ثنائي الفوسفات، الأدينوسين 28 


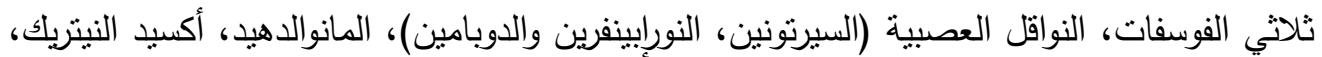

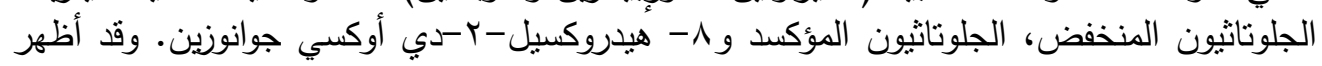

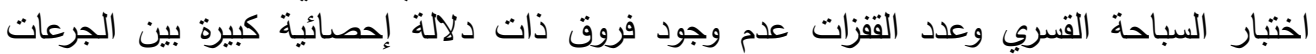

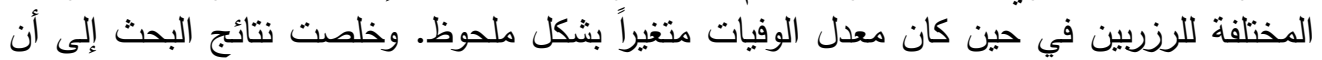

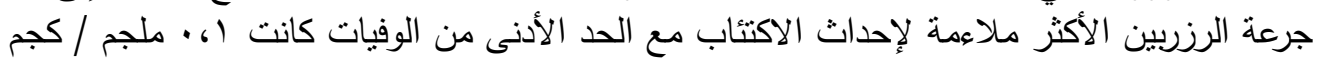

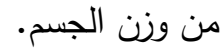
الكلمات الدالة: الاكتئاب - الرزربين. 